\title{
SELECTING AN ALGICIDE FOR USE WITH ALUMINUM ALLOYS
}

by

E. W. Wilde and B. D. McLaughlin

Savannah River Laboratory

E. I. du Pont de Nemours \& Company

Aiken, SC 29801

Proposed for publication in the

American Water Works Association Journal

This paper was prepared in connection with work under Contract No. DE-AC09-76SR00001 with the U. S. Department of Energy. By acceptance of this paper, the publisher and/or recipient acknowledges the U. S. Government's right to retain a nonexclusive, royaltyfree license in and to any copyright covering this paper, along with the right to reproduce and to authorize others to reproduce all or part of the copyrighted paper. 


\section{DISCLAIMER}

This report was prepared as an account of work sponsored by an agency of the United States Government. Neither the United States Government nor any agency thereof, nor any of their employees, makes any warranty, express or implied, or assumes any legal liability or responsibility for the accuracy, completeness, or usefulness of any information, apparatus, product or process disclosed, or represents that its use would not infringe privately owned rights. Reference herein to any specific commercial product, process or service by trade name, trademark, manufacturer, or otherwise does not necessarily constitute or imply its endorsement, recommendation, or favoring by the United States Government or any agency

thereof. The views and opinions of authors expressed herein do not necessarily state or reflect those of the United States Government or any agency thereof.

This report has been reproduced directly from the best available copy.

Available for sale to the public, in paper, from: U.S. Department of Commerce, National Technical Information Service, 5285 Port Royal Road, Springfield, VA 22161, phone: (800)

553-6847, fax: (703) 605-6900, email: orders@ntis.fedworld.gov online ordering: http://www.ntis.gov/ordering.htm

Available electronically at http://www.doe.gov/bridge

Available for a processing fee to U.S. Department of Energy and its contractors, in paper, from: U.S. Department of Energy, Office of Scientific and Technical Information, P.O. Box 62, Oak Ridge, TN 37831-0062, phone: (865 ) 576-8401, fax: (865) 576-5728, email: reports@ adonis.osti.gov 


\section{SELECTING AN ALGICIDE FOR USE WITH ALUMINUM ALLOYS}

Edward W. Wilde and Bruce D. McLaughl in

E. I. du Pont de Nemours \& Co. (Inc.) Savannah River Laboratory

Aiken, SC 29801

Date of Submission: March 1980

Telephone Number of Edward W. Wilde: (803) 725-7401

Telephone Number of Bruce D. McLaughlin: (803) 725-2245 


\section{ABSTRACT}

Six commercially available algicidal compounds were evaluated for (1) relative toxicity to various concentrations of seven species of algae and (2) potential for causing pitting corrosion of aluminum alloys. Diuron (a common herbicide) and the acetic acid salt of a technical grade of dehydroabietylamine were the two compounds moxt toxic to algae. A filming amine corrosion inhibitor ranked third in toxicity. Potassium permanganate, which ranked fourth in algicidal effectiveness, was least corrosive and was the only compound for which no pitting corrosion was measurable. Hydrogen peroxide ranked fifth in toxicity. The chlorine-liberating algicide sodium hypochlorite was found to be substantially inferior to the other five compounds in both toxicity and corrosiveness. New techniques for the evaluation of algicides are described.

Fig. I Percentages of algal cultures which required each of four minumum lethal algicidal concentrations. Comparisons between 84 cultures containing the lowest and highest initial cell densities of seven species are shown.

Fig. 2 Cyclic potentiodynamic polarization curve for 6063-Al

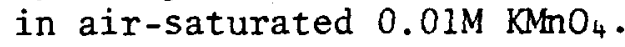

Fig. 3 Pits on 6063-Al after cyclic potentiodynamic polarization in air-saturated $0.01 \mathrm{M} \mathrm{NaOC1}$.

Fig. 4 Pit on 6063-Al after cyclic potentiodynamic polarization in air-saturated $2 \mathrm{~g} / \mathrm{L}$ DCMU.

Fig. 5 Crystallographic etching on 6063-A1 after cyclic potentiodynamic polarization in air-saturated $2 \mathrm{~mL} / \mathrm{L}$ ADA.

Fig. 6 Pit on 6063-Al after potentiostatic anodic polarization in air-saturated $2 \mathrm{~g} / \mathrm{L}$ DCMU.

Fig. 7 Crystallographic etching on 6063-A1 after potentiostatic anodic polarization in air-saturated $0.01 \mathrm{M} \mathrm{H}_{2} \mathrm{O}_{2}$. 


\section{Introduction}

Aluminum alloys are particularly susceptible to localized corrosion attack. Algicides to be used in a system constructed wholly or partially of aluminum alloys should be evaluated for their ability to cause localized corrosion. For example, copper sulfate, a common algicide, severely pits most aluminum alloys. Little information has been published about (1) the susceptibility of aluminum alloys to pitting when these alloys are exposed to aqueous solutions of algicides or (2) the effectiveness of inexpensive, commercially available algicidal chemicals except for the corrosive copper sulfate and chlorine-liberating products.

A chlorine-liberating algicide, sodium hypochlorite ( $\mathrm{NaOC} 1$ ), was found to be responsible for localized corrosion of aluminum in water basins at the Savannah River Plant near Aiken, S.C. Based on a comprehensive literature search, five commercially available chemicals were selected for evaluation and comparison with NaOCl for effectiveness as algicides and tendency to cause pitting corrosion of aluminum alloys: (1) hydrogen peroxide $\left(\mathrm{H}_{2} \mathrm{O}_{2}\right)$, potassium permanganate $\left(\mathrm{KMnO}_{4}\right)$, (3) a filming amine corrosion inhibitor* (PRAD), (4) the acetic acid salt of dehydroabietylamine ${ }^{\dagger}$ (ADA), and (5) Diuron weed killer (DCMU). PRAD and ADA are synthesized by reacting a technical grade of dehydroabietylamine with ethylene oxide and acetic acid, respectively. Diuron is $3(3,4$-dichlorophenyl) 1,1-dimethylurea and, in this investigation, was obtained by using a commercial weed killer which is a wettable powder containing $80 \%$ Diuron. ${ }^{\dagger+}$

\footnotetext{
* Polyrad ${ }_{\circledast}^{\circledR}$ liloa (Hercules Co.)

+ Amine $D^{\circledR}$ acetate $50 S$ (Hercules Co.)

t† Karmex $^{\circledR}$ (Du Pont)
} 
Methods and Materials

Algicidal effectiveness. Many authors ${ }^{1-6}$ have pointed out the large number of variables that determine the actual concentration of a chemical necessary to kill algae in a particular field situation. Experiments were thus directed toward comparing the six selected algicidal chemicals rather than determining a specific minimum lethal concentration of a specific chemical that would be applicable under all conditions.

Nonaxenic unialgal cultures of seven species representing three major algal divisions were tested. Sources of original algal material and culturing conditions for the experiments are listed in Table 1. The sixteen experiments included at least two with different initial cell densities for each algal species. All seven species had been subcultured for several months and had previously demonstrated excellent growth under the experimental conditions.

Experiments were initiated by placing $12.5-\mathrm{mL}$ of medium into each of 21 cotton-plugged 50-mL Erlenmeyer flasks. These flasks were then sterilized and $12.5-\mathrm{mL}$ aliquots of an algal culture in early to mid-exponential stage of growth were added. A $1 \mathrm{~mL}$ aliquot was microscopically analyzed to estimate the initial cell density. The six algicidal compounds were tested as received. Algicides were prepared at 1, 10, and 100 ppm by adding chemicals to the flasks; final concentrations were 1,10 , and $100 \mathrm{mg} / \mathrm{L}_{\text {of }} \mathrm{KMnO}_{4}$ and $\mathrm{DCMU}$ and 1,10 , and $100 \mu \mathrm{L} / \mathrm{L}$ of $30 \% \mathrm{H}_{2} \mathrm{O}_{2}, \mathrm{PRAD}, \mathrm{ADA}$ and $15 \% \mathrm{NaOCl}$. Three untreated flasks 
served as controls in each experiment. Flasks were placed in a temperature-controlled greenhouse (first ten experiments) or an environmental chamber equipped with a light programmer set for a $12 \mathrm{hr}$ light/12 hr dark cycle (last six experiments). Assessments of mortality were primarily based on fluorescence microscopical examinations ${ }^{9}$ of samples after treatment times of $24 \mathrm{hr}, 48 \mathrm{hr}, 1 \mathrm{wk}$, and $2 \mathrm{wk}$. This microscopical technique facilitated the differentiation between live cells containing chlorophy11 (red fluorescence emission) and recently killed cells containing chlorophyll degradation products (yellow fluorescence emission). The degree of mortality of cells treated for $24 \mathrm{hr}$ and $48 \mathrm{hr}$ with DCMU, which inhibits photosynthesis rather than causing direct cell destruction, was questionable in the microscopical examinations; consequently the subculturing technique described by Fitzgerald and Faust ${ }^{10}$ was employed at -these two time intervals. Determinations of complete mortality based on the growth of algae in subcultures were identical to the determinations made by fluorescence microscopy in all other cases.

Aluminum alloy pitting. This part of the study was to rank the six algicides according to their tendency to cause pitting of aluminum alloys. None of the generally accepted approaches to such a study precisely duplicate the phenomena observed in actual service. In theory, the best approach is to rank the algicides according to pitting potentials measured using some alloy of interest. In practice, pitting potentials cannot be reliably measured. ${ }^{11}$ 
The approach chosen for this investigation is based on three different types of tests: (1) coupon, (2) cyclic potentiodynamic polarization, and (3) potentiostatic anodic polarization. In general, the probability that a test specimen will undergo pitting corrosion in a particular algicide solution increases progressively from the coupon test to the potentiostatic test. The algicide that causes pitting in the greatest number of tests is the most aggressive pitting agent.

The solutions used in these tests were at least ten times more concentrated than would be required from an algicidal standpoint. Concentrated solutions were used in order to magnify any aggressive tendency. The concentrations used throughout were $0.01 \mathrm{M}$ solutions of $\mathrm{KMnO}_{4}, \mathrm{H}_{2} \mathrm{O}_{2}$, and $\mathrm{NaOC} 1 ; 2 \mathrm{~mL} / \mathrm{L}$ solutions of PRAD and ADA; and a $2 \mathrm{~g} / \mathrm{L}$ solution of DCMU.

Preliminary testing with a variety of alloys (1100, 6063, 8001 , and pure Al) indicated that $6063-\mathrm{Al}$ is the most susceptible to pitting corrosion. For this reason, 6063-Al was used in all pitting tests, although the coupon and cyclic potentiodynamic polarization tests were repeated with $1100-A 1$ and pure Al. These duplicate tests were consistent.

Al1 specimens were 4 by 4 by $0.1 \mathrm{~cm}$ cold-rolled 6063-Al polished with 600-grit paper. After polishing, the specimens used in the potentiostatic test were dipped in hot phosphoricnitric solution to further remove surface blemishes. 
Coupon test. Six specimens were placed in $\sim 250 \mathrm{~mL}$ of the six algicides. The solutions were changed every two weeks. After 128 days, the specimens were removed and examined by scanning electron microscopy (SEM).

Cyclic potentiodynamic polarization test. Polarization curves were obtained by (1) immersing a specimen in $\sim 500 \mathrm{~mL}$ of test solution contained in an electrochemical cell, (2) allowing the specimen to stand on open-circuit for one hour, and (3) performing cyclic polarization starting at the open-circuit potential and proceeding with descending cathodic, ascending cathodic, ascending anodic, and descending anodic scans. The extent of scan was two volts on both sides of the open-circuit potential, and the scan rate was $1 \mathrm{mv} / \mathrm{sec}$. The solutions were air saturated. Polarization curves were obtained using a PAR 173 potentiostat with logarithmic current converter, a PAR 175 universal programmer, and a PAR 9002A X-Y recorder. After polarization, each specimen was examined by SEM.

Potentiostatic anodic polarization test. Curves of opencircuit potential vs. time and applied current vs. time were obtained by (1) immersing a specimen in $\sim 500 \mathrm{~mL}$ of test solution contained in an electrochemical cell, (2) recording open-circuit potential vs. time until a steady state was achieved, (3) anodically polarizing the specimen and recording current vs. time at least until a steady state was achieved, and (4) re-establishing open circuit and repeating step 2. The solutions were air saturated. 
Data were obtained with a Wenking LB75M potentiostat and an HP 7100BM recorder. After the post-polarization open-circuit potential measurement, each specimen was examined by SEM.

\section{Results and Discussion}

Algicidal effectiveness. Table 2 shows the relative toxicity ranking of the six algicides in each of the 16 experiments. A relative value of 1 (most effective) through 6 was given to the algicides. DCMU and ADA were consistently more effective. These two were followed in order of decreasing toxicity by $\mathrm{PRAD}, \mathrm{KMnO}_{4}$, $\mathrm{H}_{2} \mathrm{O}_{2}$, and $\mathrm{NaOCl}$. The variation in ranking attributable to differential responses of the compounds to different algal species was not substantial. In fact, the variability in relative toxicity observed in two or three experiments with the same species was generally as great. Variability in results from experiments with a single species is attributed to the use of different initial cell densities and the lack of identical environmental conditions for all experiments.

The overall ranking of the six algicides was the same for all four treatment times, and 24 hours of treatment was as effective as 2 weeks of treatment for more than $50 \%$ of the samples. However, comparison of treatment times of $24 \mathrm{hr}$ and 2 wh by algicide and by taxon (Table 3 ), shows that all algicides became more effective over time in at least one experiment. PRAD increased the most in algicidal effectiveness during the two-week treatment periods. Among taxa, the diatom Nitaschia required the longest 
treatment time to be killed, probably because diatom cells contain a siliceous frustule, or shell, which may reduce the speed at which toxic chemicals can penetrate the cells.

The necessary concentration of all six algicides appeared to be directly proportional to the density of algae subjected to treatment (Fig. 1). The amount of toxicant per cell is undoubtedly an important criterion in the determination of the minimum lethal concentration of any algicide. ${ }^{4}$

Aluminum alloy pitting. The appearance of each of the coupon test specimens is described in Table 4 . The precipitate on the specimen exposed to $\mathrm{KMnO}_{4}$ solution was probably $\mathrm{MnO}_{2}$ formed during the spontaneous reduction of $\mathrm{MnO}_{4}^{-}$. The complementary oxidation process was the oxidation of aluminum with no contribution from the oxidation of water because the open-circuit potential of $6063-\mathrm{Al}$ in $\mathrm{KMnO}_{4}$ is more negative than the reversible potential for oxygen evolution (see Table 5). The precipitate on the specimen exposed to PRAD solution resulted because $P R A D$ is a filming amine. A film was also observed on the specimen exposed to ADA solution. In the coupon test, pitting occurred on $1 y$ on the specimen exposed to NaOC1 solution.

A typical cyclic potentiodynamic polarization curve is shown in Fig. 2. The cathodic portion of a cyclic potentiodynamic scan is useful as a final cleaning step, but it provides no information concerning pitting susceptibility. However, pitting susceptibility can be predicted fairly reliably from the anodic 
portion of a scan. If the descending anodic curve is shifted to lower currents (positive hysteresis) or if the descending curve essentially retraces the ascending curve (neutral hysteresis), the solution is not an aggressive pitting agent and no pitting is expected. However, if the descending curve is shifted to higher currents than the ascending curve (negative hysteresis), the solution is probably an aggressive pitting agent and pitting is expected. Figure 2 shows an example of positive hysteresis. For this study, anodic hysteresis was measured by subtracting the descending current density from the ascending current density measured at a potential $1000 \mathrm{mV}$ more noble than the open-circuit. potential. Another approach would be to determine the area enclosed between ascending and descending curves. The concept of anodic hysteresis can assist in the determination of pitting susceptibility; particularly when well defined pits do not develop during cyclic polarization.

Anodic hysteresis values are given in Table 6 . Hysteresis was positive with $\mathrm{KMnO}_{4}$ solution, with no pitting. Hysteresis was also positive with PRAD, with no pitting. With $\mathrm{H}_{2} \mathrm{O}_{2}$ solution, hysteresis was nearly neutral with no observable pitting. With NaOCl solution, hysteresis was strongly negative, and the test specimen was speckled with well defined pits (Fig. 3). Hysteresis was also negative with DCMU solution and pitting was extensive (Fig. 4). ADA solution produced a fairly strong negative hysteresis, but not pitting. Isolated regions of surface damage were apparent 
however, and this damage took the form of superficial crystallographic etching (Fig. 5). In this instance, crystallographic etching may logically be viewed as a precursor to pitting because (1) substantial negative hysteresis was observed during cyclic polarization in ADA solution and (2) crystallographic etching of the type shown in Fig. 5 is nearly identical to the structure observed in the interior of pits produced in $6063-\mathrm{A} 1$ by either potentiodynamic or potentiostatic anodic polarization.

In the cyclic potentiodynamic polarization test, specimens exposed to NaOCl solution and DCMU solution were pitted. Surface damage, in the form of crystallographic etching (a precursor to pitting), was observed on the specimen exposed to ADA solution.

In the potentiostatic anodic polarization test, 6063-Al was anodically polarized at potentials near $1000 \mathrm{mv}$ more noble than the steady-state pre-polarization open-circuit potentials. Wellestablished pitting was observed with solutions of $\mathrm{NaOCl}$, DCMU, $A D A$, and PRAD. The interior of each pit possessed a crystallographic structure similar to that shown in Fig. 5. Figure 6 shows a typical pit. Pitting was not observed with $\mathrm{H}_{2} \mathrm{O}_{2}$ solution, but the specimen surface was characterized by etched regions (Fig. 7). The structure in Fig. 7 is not as well defined as that in Fig. 5, but its crystallographic nature is still apparent. In this instance, crystallographic etching may not be a precursor to pitting because both surface damage and substantial negative hysteresis were absent in the cyclic potentiodynamic polarization 
test. No pitting or surface damage was observed on the specimen exposed to $\mathrm{KMnO}_{4}$ solution.

Additional results of the potentiostatic anodic polarization test are contained in Table 5. For each algicide, the steadystate pre-polarization open-circuit potential was more positive than the steady-state post-polarization open-circuit potential. The decrease in open-circuit potential was most pronounced for those algicides that did not cause pitting. Also, for each algicide, the pre-polarization and post-polarization open-circuit potentials were more negative than the reversible potential for oxygen evolution. Because the solutions were saturated in air, oxygen was probably reduced under open-circuit conditions in all six algicidal solutions. Reduction of oxygen was probably the dominant open-circuit reduction process in solutions of the three organic materials. In solutions of $\mathrm{KMnO}_{4}, \mathrm{H}_{2} \mathrm{O}_{2}$, and $\mathrm{NaOCl}$, the reduction of oxygen was supplemented by the reduction of $\mathrm{MnO}_{4}^{-}$ to $\mathrm{MnO}_{2}, \mathrm{H}_{2} \mathrm{O}_{2}$ to $\mathrm{H}_{2} \mathrm{O}$, and $\mathrm{ClO}^{-}$to $\mathrm{Cl}^{-}$, respectively.

In the potentiostatic anodic polarization test, pitting occurred on the specimens exposed to NaOCl, DCMU, ADA, and PRAD solutions. Surface damage, in the form of crystallographic etching, was observed on the specimen exposed to $\mathrm{H}_{2} \mathrm{O}_{2}$ solution.

The results of the pitting study are summarized in Table 7 . The algicides may be ranked in the following order (starting with the least aggressive): $\mathrm{KMnO}_{4}, \mathrm{H}_{2} \mathrm{O}_{2}, \mathrm{PRAD}, \mathrm{ADA}, \mathrm{DCMU}$, and $\mathrm{NaOC} 1$. The average steady-state current densities, obtained during 
potentiostatic anodic polarization, reflect essentially the same order, with the least aggressive pitting agent producing the lowest current density (see Table 5). Thus, during potentiostatic anodic polarization, the oxidation process is dominated by anodic dissolution in pits, with other processes (such as the oxidation of water) proceeding at a substantially slower rate.

Conclusions

Five relatively noncorrosive commercially available compounds were compared with one another and with sodium hypochlorite for their potential applicability as algicides in water systems containing aluminum alloys. Potassium permanganate $\left(\mathrm{KMnO}_{4}\right)$ appeared to be the most suitable compound when corrosion prevention is of prime concern. This algicide ranked fourth in terms of algicidal effectiveness, but was the only compound for which no pitting corrosion or surface damage of any type was observed in the most sensitive (potentiostatic anodic polarization) corrosion test. Use of $\mathrm{KMnO}_{4}$ as an algicide has previously been reported.12-18 Hydrogen peroxide $\left(\mathrm{H}_{2} \mathrm{O}_{2}\right)$ and $\mathrm{PRAD}$, which ranked fifth and third, respectively, in toxicity tests, showed very slight corrosion potential and would probably be suitable in situations where trivial corrosion could be tolerated. $\mathrm{H}_{2} \mathrm{O}_{2}$ has been recommended for use in cooling towers in Czechoslovakia. ${ }^{19}$ PRAD is a corrosion inhibitor when used in systems containing stainless steel. Its effectiveness as an algicide has not previously been reported. 
The herbicide diuron (DCMU) and ADA were the two most effective compounds for killing algae. Corrosion testing, however, indicated that some pitting of aluminum could be expected from repeated use of either of these compounds. Sodium hypochlorite was substantially inferior to the other five compounds both in terms of toxicity to algae and aluminum corrosion.

\section{ACKNOWLEDGEMENT}

The information contained in this article was developed during the course of work under Contract No. DE-AC09-76SR00001 with the U. S. Department of Energy. 


\section{References}

1. Fitzgerald, G. P., Factors in the Testing and Application of Algicides. App1. Microbiol., 12:3: 247 (May 1964).

2. Funk, W. H. \& Gaufin, A. R., Control of Taste and OdorProducing Algae in Deer Creek Reservoir. Trans. Amer. Micros. Soc. 84: 263 (1965).

3. Beddow, D. G., Schilichting, H. E. \& Vance, B. D. The Survival of Some Algae in Highly Chlorinated Water. Adv. Frontiers Plant Sci., 19: 165 (1968).

4. Fitzgerald, G. P., Algicides. Wisconsin Water Resources Center, NTIS Publ. 198130 (Feb. 1971).

5. Goulding, K. H., A Preliminary Investigation of a Potential New Algicide. Proc. 6th Br. Insecticide Conf., 621 (1971).

6. Muchmore, C. B., Algae Control in Water Supply Reservoirs. Illinois Institute for Environmental Quality Rept. NTIS Pub1. 226275 (July 1973).

7. Castenholz, R. W., Thermophilic Blue-Green Algae and the Thermal Environment. Bact. Rev. 33: 476 (Dec. 1969).

8. Guillard, R. R. L. \& Ryther, J. H., Studies on Marine Planktonic Diatoms. I. CycloteZza nana Hustedt. and Detonula conferualea (Cleve) Gran. Can. J. Microbio1. 8: 229 (1962).

9. Wilde, E. W. \& Fliermans, C. B., Fluorescence Microscopy for Algal Studies. Trans. Amer. Micros. Soc., 98: 96 (Jan. 1979).

10. Fitzgerald, G. P. \& Faust, S. L., Factors Affecting the Algicidal and Algistatic Properties of Copper. Appl. Microbiol. $11: 355$ (1963).

11. Manning, E. P., Duquette, D. J. \& Savage, W. F., The Effect of Test Method and Surface Condition on Pitting Potential of Single and Duplex Phase 304L Stainless Steel. Corrosion, $35: 4: 151$ (1979). 
12. Cherry, A. K., Use of Potassium Permanganate in Water Treatment. Jour. A.W.W.A. 54:4: 417 (Apr. 1962).

13. Welch, W. A., Potassium Permanganate in Water Treatment. Jour. A.W.W.A. 55:6:735 (June 1963).

14. Rauch, W. D., Permanganate Treatment of Water. Water Works and Wastes. Eng. 1: 36 (Nov. 1964).

15. Fitzgerald, G. P., Laboratory Evaluation of Potassium Permanganate as an Algicide for Water Reservoirs. Southwest Water Works J., 45:10: 16 (Jan. 1964).

16. Fitzgerald, G. P., Evaluation of Potassium Permanganate as an Algicide for Water Cooling Towers. I and E.C. Prod. Res. and Devel., 3:2: 82 (June 1964).

17. Fitzgerald, G. P., Use of Potassium Permanganate for Control of Problem Algae. Jour. A.W.W.A. 58:5:609 (May 1966).

18. Kemp, H.T., Fuller, R. G. \& Davison, R. S., Potassium Permanganate as an Algicide. Jour. A.W.W.A. 58:2: 255 (Feb. 1966).

19. Sladeckova, A., Control of S1imes and Algae in Cooling Systems. Verh. Internat. Verein. Limnol. 17:532 (Nov. 1969). 
Algal Species and Environmental Conditions for Experiments

Taxon

Cyanophyta (Blue-green algae) Mastigocladus Zaminosus Cohn Chlorophyta (Green algae)

Coelastrum combricum Archer

Source

UTEX $^{+}$

Z-USC ${ }^{\dagger}$

Selenastrom copricomutum Printz EPA-C $C^{\S}$

ChZamydomonas reinhardtii Dang. Z-USC

Cosmarium subcostatum Nordst

Chzorezza sp.

UTEX

Z-USC

Bacillariophyta (Diatoms)

Nitzschia palea (Kutz.) W.Smith U3RC ${ }^{\star *}$
Culture Conditions

\begin{tabular}{lll}
\hline Temp., & Light, \\
${ }^{\circ} \mathrm{C}$ & $\underline{\mathrm{ft}^{-} \mathrm{C}^{\star}} \quad$ Media \\
\hline
\end{tabular}

45

50

$0^{7}$

20

100

$\mathrm{F} / 2^{8}$

20

100

$F / 2$

20

100

$F / 2$

20

100

$\mathrm{F} / 2$

20

100

$\mathrm{F} / 2$

20

100

$F / 2$

* Environmental chamber experiments only (12 hr per day)

+ UTEX $=$ University of Texas culture collection at Austin.

$\ddagger Z$ Z-USC $=$ Dr. Richard G. Zingmark, Univ. of S.C., Columbia.

§ $E P A-C=$ Environmental Protection Agency, Corvallis, Ore.

** U3RC = Isolated from Upper Three Runs Creek, Aiken, County, S.C. 
TABLE 2

Toxicity Ranking of Six Algicidal Compounds (Two-week Treatment)

\begin{tabular}{|c|c|c|c|c|c|c|c|}
\hline Algal Species & $\begin{array}{c}\text { Initial Cell } \\
\text { Density, } \\
\text { cells/mL } \\
\end{array}$ & DCMU & $\underline{A D A}$ & PRAD & $\mathrm{KMnO}_{4}$ & $\underline{\mathrm{H}_{2} \mathrm{O}_{2}}$ & $\mathrm{NaOCl}$ \\
\hline Selenastrum capricornutiom & $1.2 \times 10^{5}$ & 2.5 & 2.5 & 2.5 & 2.5 & 5.5 & 5.5 \\
\hline SeZenastmom capricormutum & $2.0 \times 10^{5}$ & 2.5 & 2.5 & 2.5 & 2.5 & 5.0 & 6.0 \\
\hline SeZenastrum capricornutum & $9.1 \times 10^{5}$ & 1.5 & 1.5 & 4.0 & 4.0 & 4.0 & 6.0 \\
\hline Chzomydomonas reinhardtii & $1.0 \times 10^{4}$ & 1.0 & 2.5 & 2.5 & 5.0 & 5.0 & 5.0 \\
\hline Chzamydomonas reinhardtii & $5.5 \times 10^{4}$ & 2.0 & 2.0 & 2.0 & 5.0 & 5.0 & 5.0 \\
\hline Cosmarium subcostatum & $4.2 \times 10^{2}$ & 1.5 & 1.5 & 3.0 & 4.5 & 4.5 & 6.0 \\
\hline Cosmarium subcostatum & $1.2 \times 10^{4}$ & 1.5 & 1.5 & 3.0 & 4.5 & 4.5 & 6.0 \\
\hline Chzorezza sp. & $9.3 \times 10^{4}$ & 2.5 & 1.0 & 2.5 & 4.5 & 4.5 & 6.0 \\
\hline Chzorezza sp. & $1.0 \times 10^{6}$ & 2.0 & 2.0 & 2.0 & 4.5 & 4.5 & 6.0 \\
\hline Coelastrum cambricum & $4.3 \times 10^{4}$ & 2.0 & 2.0 & 2.0 & 4.5 & 4.5 & 6.0 \\
\hline Coelastrum combricum & $2.0 \times 10^{5}$ & 1.0 & 2.0 & 3.5 & 3.5 & 5.5 & 5.5 \\
\hline Mastigocladus Zaminosus & $2.5 \times 10^{3}$ & 2.0 & 2.0 & 2.0 & 4.5 & 4.5 & 6.0 \\
\hline Mastigocladus Zaminosus & $1.5 \times 10^{4}$ & 1.5 & 1.5 & 3.5 & 3.5 & 5.5 & 5.5 \\
\hline Mastigocladus Zaminosus & $4.0 \times 10^{6}$ & 2.0 & 2.0 & 2.0 & 5.0 & 5.0 & 5.0 \\
\hline Nitzschia palea & $7.5 \times 10^{3}$ & 1.5 & 1.5 & 3.0 & 4.5 & 4.5 & 6.0 \\
\hline Nitzschia palea & $2.0 \times 10^{5}$ & 1.0 & 2.5 & 2.5 & 4.5 & 4.5 & 6.0 \\
\hline & & 28.0 & 30.5 & 42.5 & 67.0 & 76.5 & 91.5 \\
\hline
\end{tabular}




\section{TABLE 3}

Percent of Samples in which a Two-Week Treatment was more Effective than a 24-Hour Treatment

By Algicide

PRAD $\quad 68.8 \%$

ADA $\quad 37.5 \%$

DCMU $\quad 25.0 \%$

$\mathrm{H}_{2} \mathrm{O}_{2} \quad 18.8 \%$

$\mathrm{KMnO}_{4} \quad 12.5 \%$

$\mathrm{NaOCl} \quad 12.5 \%$
By Algal Taxon

Nitzschia $\quad 66.7 \%$

Chramydomonas $\quad 50.0 \%$

ChIorezza 25.0\%

Mastigocladus $22.2 \%$

Cosmarizom $\quad 16.7 \%$

Coezastrum $\quad 16.7 \%$

SeZenastrom $\quad 11.1 \%$ 
TABLE 4

Coupon Tests (128 days in solution)

Concentration

of

Algicide Test Solution

$\mathrm{KMnO}_{4}$

$10^{-2} \mathrm{M}$

Appearance of Test Specimen

$\mathrm{H}_{2} \mathrm{O}_{2}$

$10^{-2} \mathrm{M}$

Light brown; surface partially covered

by particles of hemispherical precipitate

Coated with aluminum oxide; speckled but no pits

PRAD $2 \mathrm{~mL} / \mathrm{L}$

Dull gray; coated with a thin, non-oxide, continuous film

ADA $2 \mathrm{~mL} / \mathrm{L}$

Dull gray; coated with a thin, non-oxide film

DCMU

$2 \mathrm{~g} / \mathrm{L}$

Slight blue; no evidence of coating detectable using SEM

$\mathrm{NaOCl} \quad 10^{-2} \mathrm{M}$

Coated with aluminum oxide; speckled with pits 


\section{TABLE 5}

Potentiostatic Anodic Polarization Test Information

\begin{tabular}{|c|c|c|c|c|c|c|c|c|}
\hline Algicide & $\begin{array}{c}\text { Concentration } \\
\text { of } \\
\text { Test Solution }\end{array}$ & $\begin{array}{c}\text { Initial } \\
\mathrm{pH} \\
\end{array}$ & $\begin{array}{l}\text { Steady State } \\
\text { Pre- } \\
\text { PoTarization } \\
\text { Open Circuit } \\
\text { Potential, } \\
\text { mV vs. SCE } \\
\end{array}$ & $\begin{array}{l}\text { Steady State } \\
\text { Post- } \\
\text { Polarization } \\
\text { Open Circuit } \\
\text { Potential, } \\
\text { mV vs. SCE } \\
\end{array}$ & $\begin{array}{l}\text { Reversible } \\
\text { Potential for } \\
\mathrm{O}_{2}+2 \mathrm{H}_{2} \mathrm{O} \\
+4 \mathrm{e}^{-} \rightarrow \mathrm{SOH}^{-} \\
\mathrm{mV} \text { vs. SCE }\end{array}$ & $\begin{array}{l}\text { Potentio- } \\
\text { static } \\
\text { Polarization } \\
\text { Potential, } \\
\text { mV vS. SCE }\end{array}$ & $\begin{array}{l}\text { Duration of } \\
\text { Potentio- } \\
\text { static } \\
\text { Polarization, } \\
\text { hours } \\
\end{array}$ & $\begin{array}{l}\text { Average } \\
\text { Steady State } \\
\text { Current } \\
\text { Density, } \\
\mu \mathrm{A} / \mathrm{cm}^{2} \\
\end{array}$ \\
\hline $\mathrm{KMnO}_{4}$ & $10^{-2} \mathrm{M}$ & 8.7 & +305 & -250 & +461 & +1000 & 71.7 & .28 \\
\hline $\mathrm{H}_{2} \mathrm{O}_{2}$ & $10^{-2} \mathrm{M}$ & 7.4 & -180 & -900 & +538 & +1000 & 24.0 & 1.3 \\
\hline PRAD & $2 \mathrm{~mL} / \mathrm{L}$ & 8.2 & -500 & -590 & +491 & +700 & 30.5 & 52.0 \\
\hline ADA & $2 \mathrm{~mL} / \mathrm{L}$ & 6.2 & -420 & -780 & +609 & +500 & 71.5 & 110.0 \\
\hline DCMU & $2 \mathrm{~g} / \mathrm{L}$ & 9.3 & -460 & -700 & +426 & +500 & 17.7 & 62 \\
\hline $\mathrm{NaOCl}$ & $10^{-2} \mathrm{M}$ & 10.9 & -620 & -950 & +331 & +350 & 6.5 & 3100 \\
\hline
\end{tabular}

* Calculated from $E=\left(401-59.1 \log \left[\mathrm{OH}^{-}\right]+14.7 \log \mathrm{Po}_{2}\right)-242$ using $\mathrm{PO}_{2}=0.2 \mathrm{ATM}$ and $10 \mathrm{~g}\left[\mathrm{OH}^{-}\right]=\mathrm{pH}-14$ and the tabulated $\mathrm{pH}$ values. 
TABLE 6

Cyclic Potentiodynamic Polarization Tests

\begin{tabular}{lccc} 
Algicide & $\begin{array}{c}\text { of } \\
\text { Test Solution }\end{array}$ & $\begin{array}{c}\text { After One Hour, } \\
\mathrm{mV} \text { Vs. SCE }\end{array}$ \\
${$\cline { 2 - 2 }$} }$ & $10^{-2} \mathrm{M}$ & +279 \\
$\mathrm{H}_{2} \mathrm{O}_{2}$ & $10^{-2} \mathrm{M}$ & -254 \\
$\mathrm{PRAD}$ & $2 \mathrm{~mL} / \mathrm{L}$ & -937 \\
$\mathrm{ADA}$ & $2 \mathrm{~mL} / \mathrm{L}$ & -579 \\
$\mathrm{DCMU}$ & $2 \mathrm{~g} / \mathrm{L}$ & -501 \\
$\mathrm{NaOCl}$ & $10^{-2} \mathrm{M}$ & -666
\end{tabular}

Hysteres is at Pre-Polarization Open Circuit Potential Pre-Polarization Open Circuit Potential Plus One Volt, $\mu \mathrm{A} / \mathrm{cm}^{2}$

$+7.5$

$-0.09$

$+4.3$

$-125$

$-15.6$

$-500$ 


\section{TABLE ?}

Results of SEM Examination for Pitting of Test Specimens

\begin{tabular}{|c|c|c|c|}
\hline Algicide & $\begin{array}{l}\text { Coupon } \\
\text { Test } \\
\end{array}$ & $\begin{array}{c}\text { Cyclic } \\
\text { Potentiodynamic } \\
\text { Polarization } \\
\text { Test } \\
\end{array}$ & $\begin{array}{c}\text { Potentiostatic } \\
\text { Anodic } \\
\text { Polarization } \\
\text { Test } \\
\end{array}$ \\
\hline $\mathrm{KMnO}_{4}$ & NP & NP & NP \\
\hline $\mathrm{H}_{2} \mathrm{O}_{2}$ & NP & NP & $N P / S D$ \\
\hline PRAD & NP & NP & $P$ \\
\hline$A D A$ & NP & NP/SD & $P$ \\
\hline DCMU & NP & $P$ & $P$ \\
\hline $\mathrm{NaOCl}$ & $P$ & $P$ & $P$ \\
\hline
\end{tabular}

P Pitted

NP Not Pitted

SD Surface damage in the form of crystallographic etching 


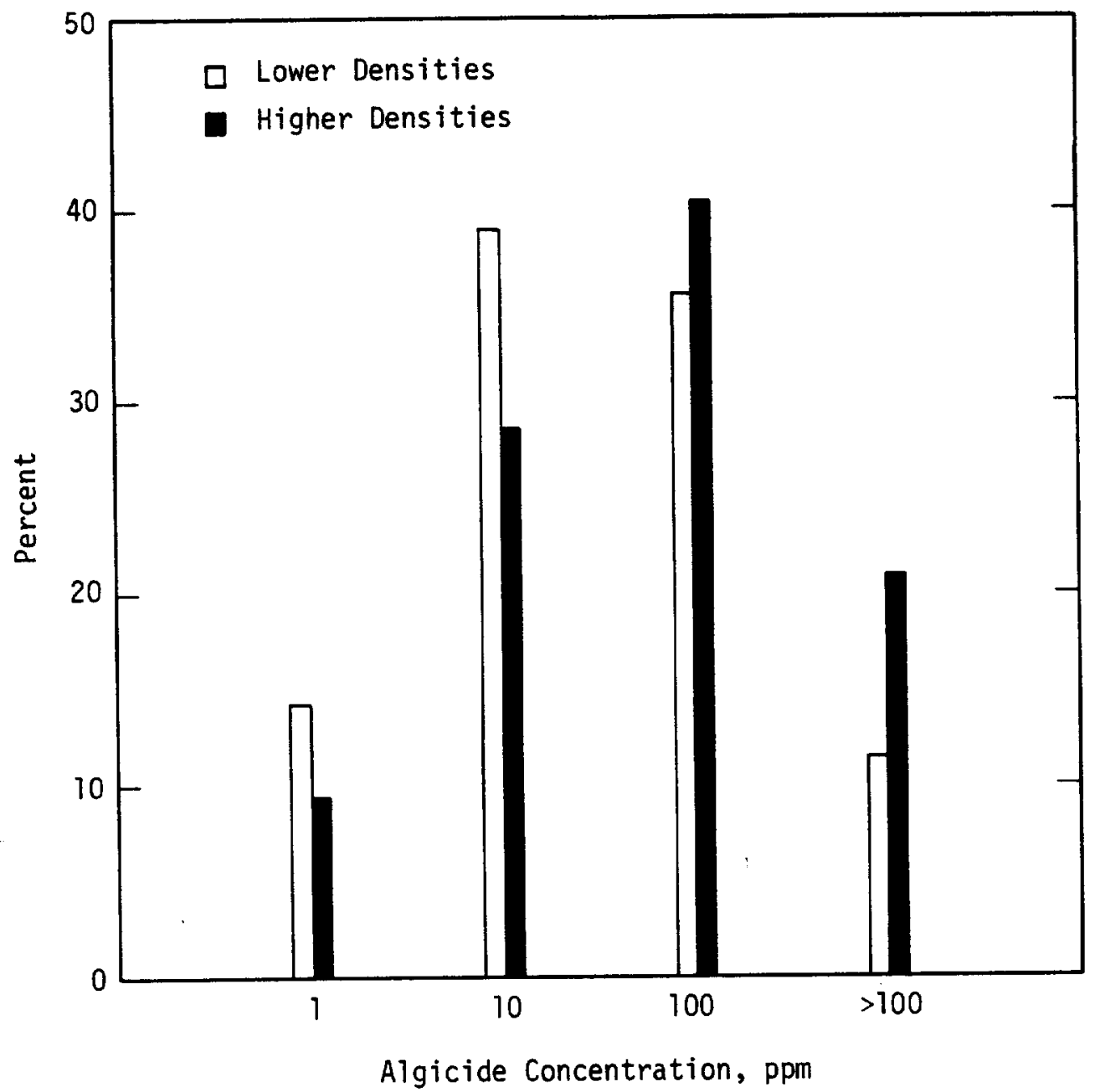

FIGURE 1. Percentages of algal cultures which required each of four minimum lethal algicidal concentrations. Comparisons between 84 cultures containing the lowest and highest initial cell densities of seven species are shown. 


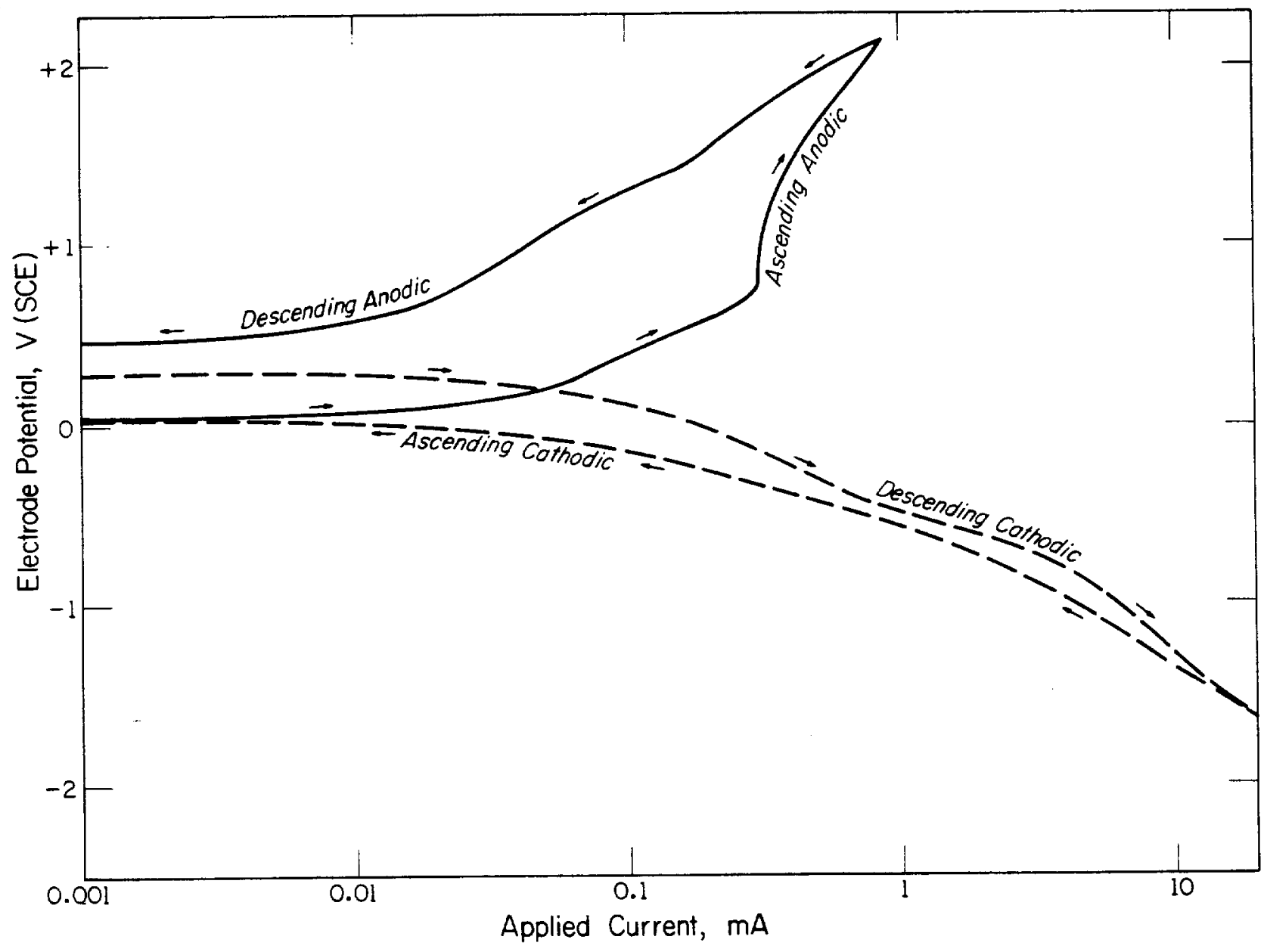

Fig. 2. Cyclic Potentiodynamic Polarization Curve for 6063-A7 in Air Saturated $0.01 \mathrm{M} \mathrm{KMnO}_{4}$ 


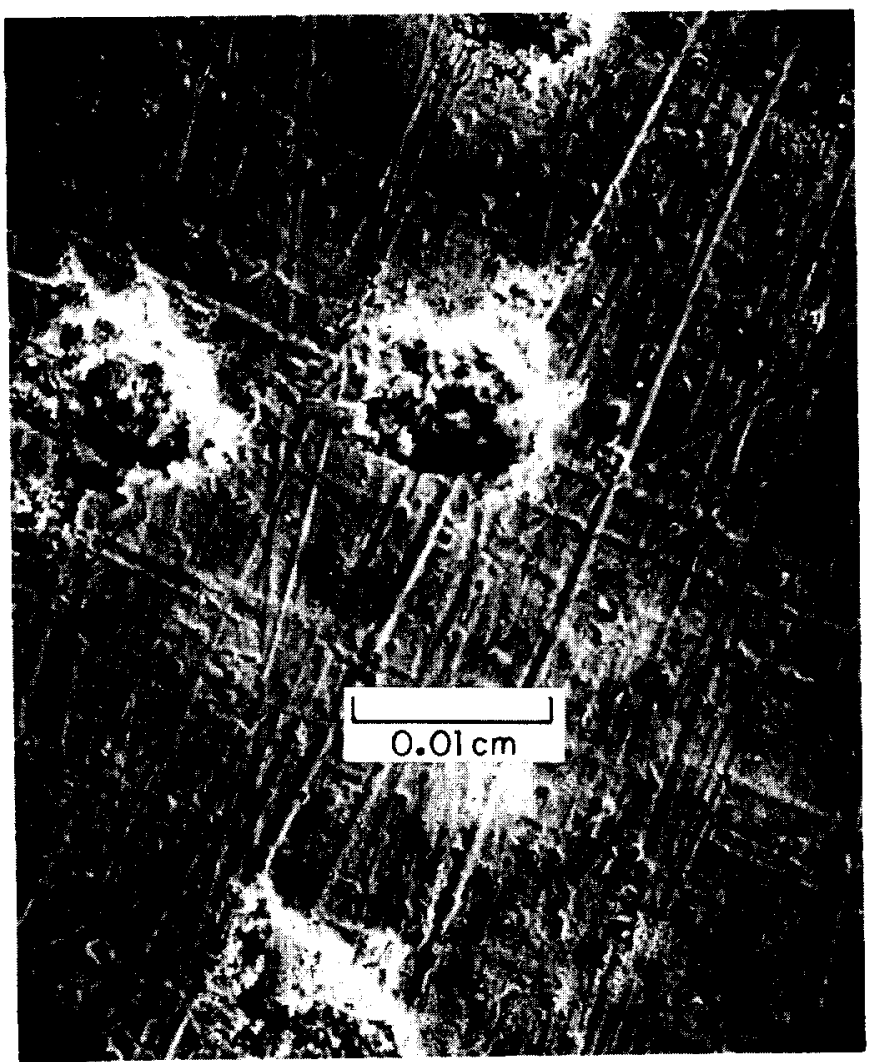

Fig. 3. Pits on 6063-Al After Cyclic Potentiodynamic Polarization in Air Saturated $0.01 \mathrm{M} \mathrm{NaOCl}$ 


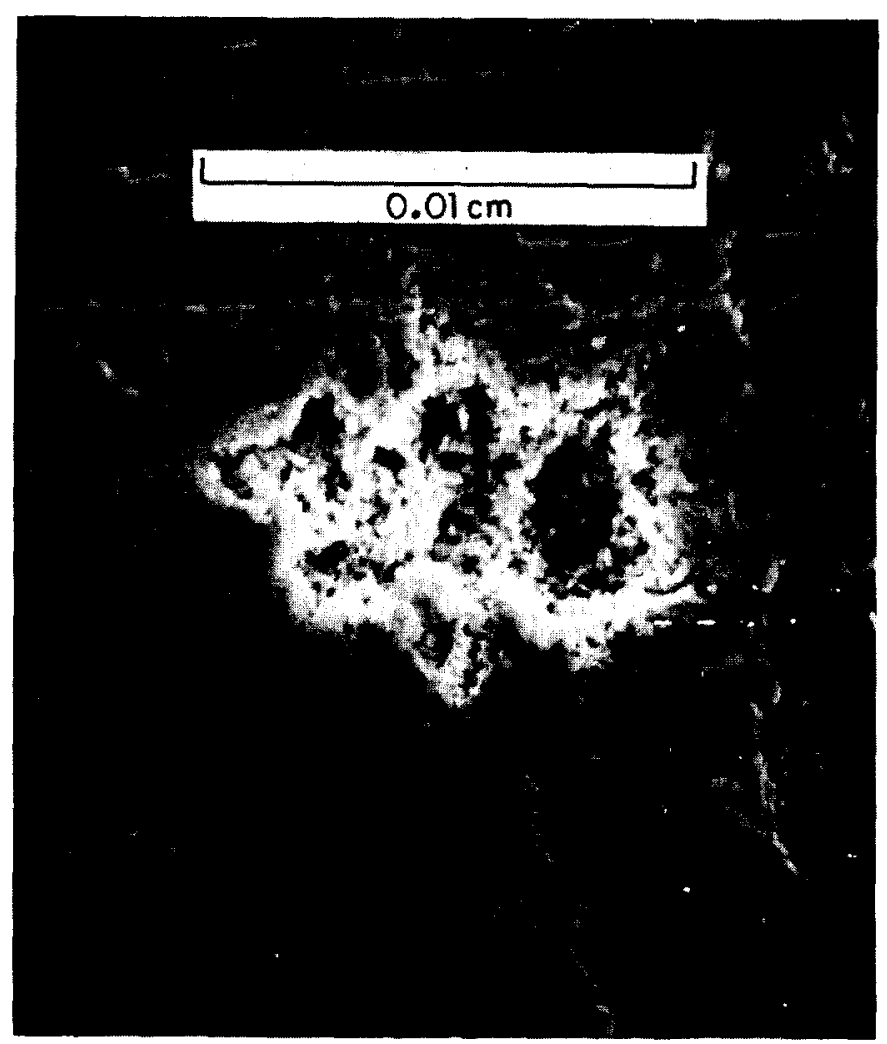

Fig. 4. Pit on 6063-A1 After Cyclic Potentiodynamic Polarization in Air Saturated $2 \mathrm{~g} / \mathrm{L}$ DCMU 


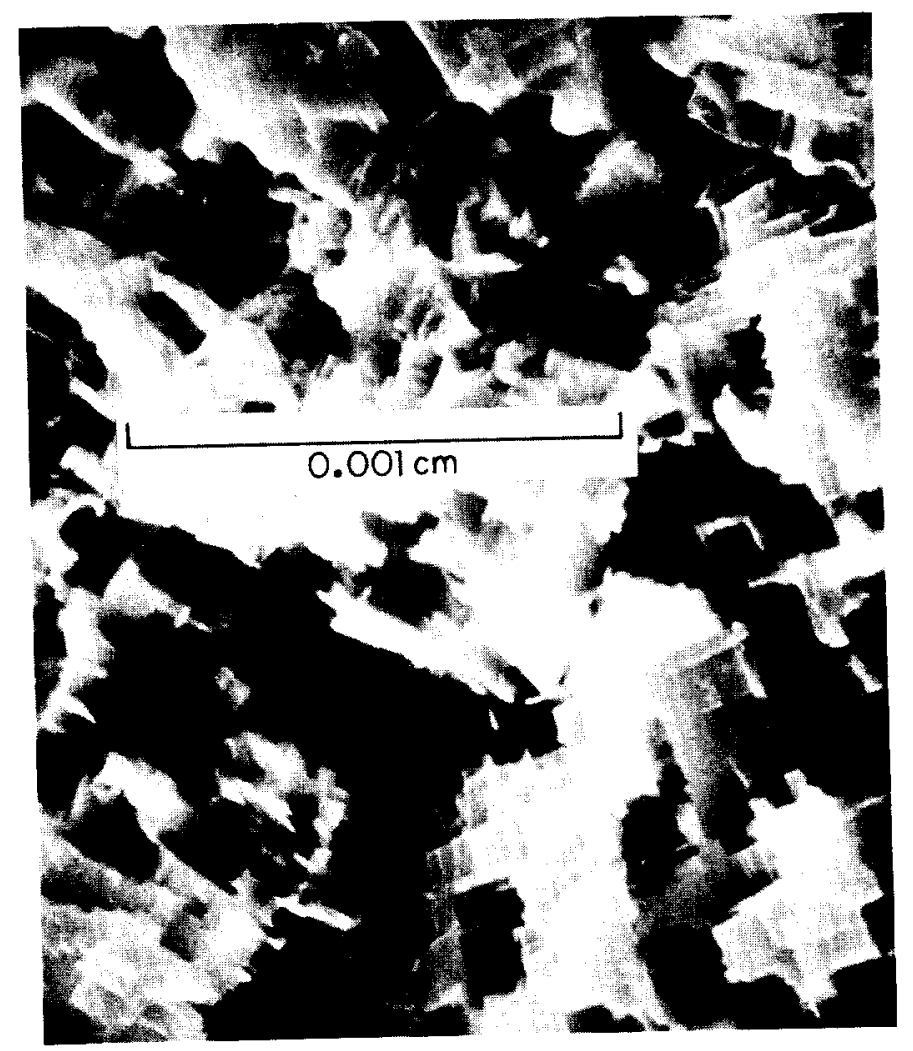

Fig. 5. Crystallographic Etching on 6063-Al After Cyclic Potentiodynamic Polarization in Air Saturated $2 \mathrm{~mL} / L$ ADA 


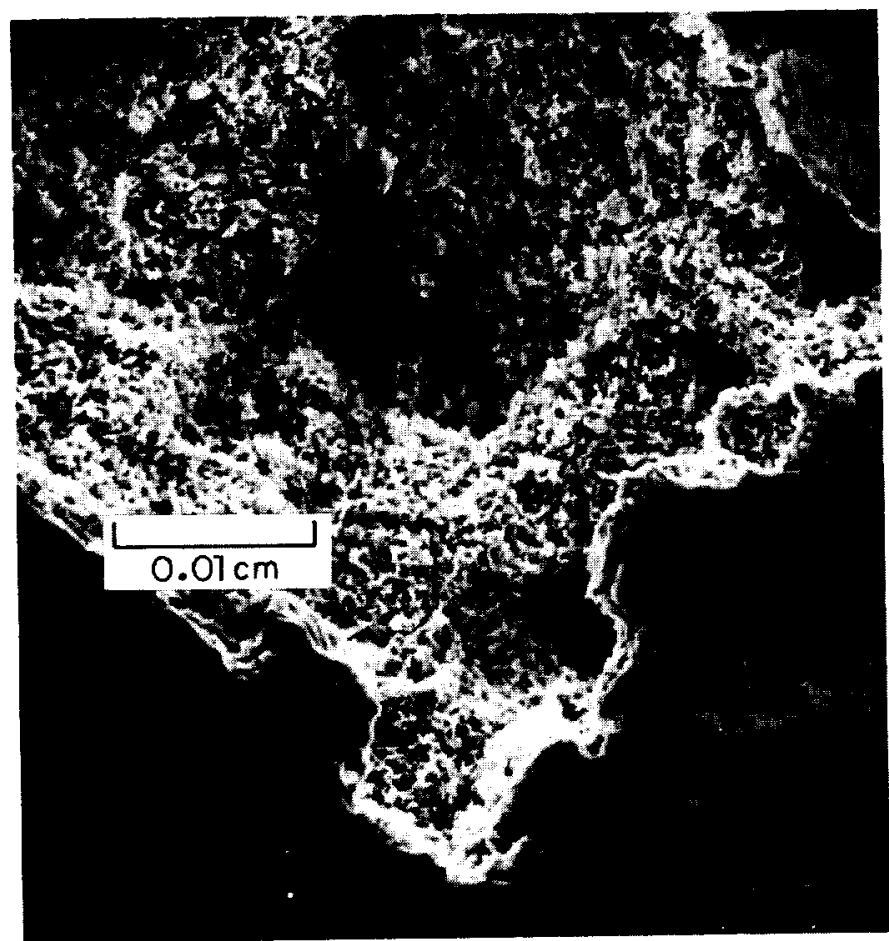

Fig. 6. Pit on 6063-Al After Potentiostatic Anodic Polarization in Air Saturated $2 \mathrm{~g} / \mathrm{L}$ DCMU 


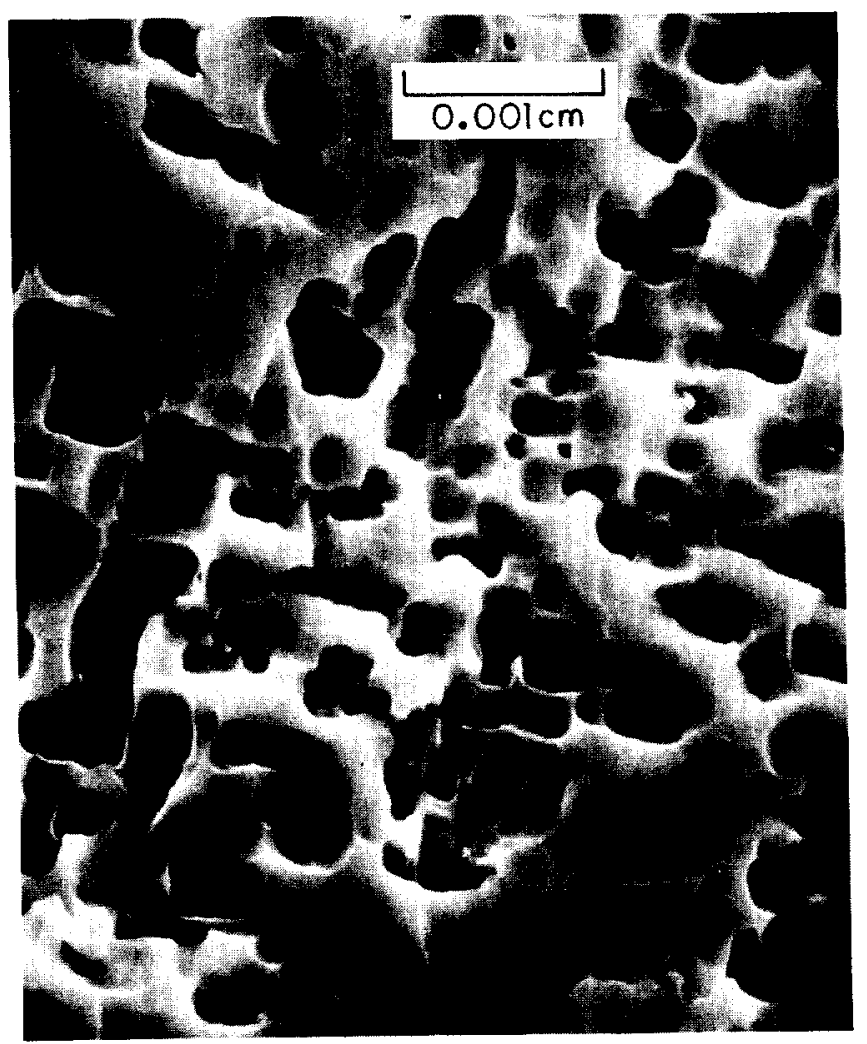

Fig. 7. Crystallographic Etching on 6063-Al After Potentiostatic Anodic Polarization in Air Saturated $0.01 \mathrm{M}_{2} \mathrm{O}_{2}$ 